UDC 614.876:614.31]:639.21

\title{
TO EVALUATION OF RADIATION SAFETY DUE TO CONSUMPTION OF SPECIES FISHED OUT IN THE FAR EAST REGION
}

\author{
G.G. Onishenko ${ }^{1}$, N.V. Zaitseva ${ }^{2}$, P.Z. Shur ${ }^{2}$, D.A. Kirianov ${ }^{2}$, \\ V.M. Chigvintsev ${ }^{2}$, A.A. Khasanova ${ }^{2}$, S.Yu. Balashov ${ }^{2}$ \\ ${ }^{1}$ RF Government Apparatus \\ ${ }^{2}$ FBSI "Federal Scientific Center for Medical and Preventive \\ Health Risk Management Technologies”, Russian Federation, Perm, 82 Monastyrskaya St., 614045
}

Results of safety assessment for population of the Russian Federation due to consumption of the Far East region commercial fish contaminated in consequence of the Fukushima nuclear disaster are presented. Estimation of radionuclide level in certain commercial fish species taking into account maximum ${ }^{137} \mathrm{Cs}$ contamination rate of ocean water on the migration path was performed. Authors worked out 3 fish products consumption scenarios and calculated respective annual ${ }^{137}$ Cs intakes. Assessment of health risk associated with ${ }^{137}$ Cs in fish products for Russian population was carried out. It was determined that in 2014 maximum ${ }^{137} \mathrm{Cs}$ dose received with fish products was no more than $365 \mathrm{~Bq} /$ year and considered as permissible health risk level. Cancer risk evolution modeling showed that lifetime cancer risk level is minimal. Hence, monitoring of associated with ${ }^{137}$ Cs water pollution health risk had to be continued till complete elimination of consequences of Fukushima-1 accident.

Key words: health risk assessment, cesium, fish, Fukushima-1

Due to the Fukushima-1 accident occurred in March 2011 a large amount of radionuclides was discharges to the north part of Pacific Ocean which because of transfer by sea currents reached the USA and affected the sea water quality in the whole aquatic $\mathrm{cm}$. The intake of radionuclides from the failed station to Pacific Ocean occurred both by air and as a result of uncontrolled discharge of water to the ocean used for colling the failed reactors [3]. According to the different assessments $1 \cdot 10^{15}$ to $41 \cdot 10^{15} \mathrm{~Bq}{ }^{137} \mathrm{Cs}$ and the same amount of ${ }^{134} \mathrm{Cs}[1,3]$ was discharged directly to the ocean with water; the significant share of radionuclides discharged to atmosphere has fallen out on the surface of the northern part of Pacific Ocean.

The intake of radionuclides to the ocean water resulted in the radioactive contamination of sea fish the fishing of which is performed both in the water of Pacific Ocean and the Sea of Japan and Sea of Okhotsk connected by narrow straits with Pacific Ocean [1]. The materials on the cesium isotopes content in the sea products extracted in the Japanese nearshore water are regularly published in the press-releases and monthly reports of the Ministry of Health of Japan. About $2 \%$ of the fish samples catched at the eastern shore of Japan in 2012 exceed the EU standard for the permissible content of ${ }^{137} \mathrm{Cs}$ and $10 \%$ of samples exceed the Russian Federation standard [1]. This demonsrates the hazard for the health of population of the Russian Federation stipulated by the intake of radionuclides ${ }^{137} \mathrm{Cs}$ and ${ }^{134} \mathrm{Cs}$ with fish and seafood living in the contaminated sea water.

The alimentary intake is a prevailing way of intake of ${ }^{137} \mathrm{Cs}$ to the fish body [6]. The continuous transfer of substance occurs between the components of food webs, and therefor the radionuclides can migrate by the food webs from the one level to another [12]. Due to this fact, the transfer of radioactive substances by the food chains is the most important way of intake of radionuclides to the fish body.

The intake of ${ }^{137} \mathrm{Cs}$ as well as the other radionuclides by fish to a large extent depends on its

(c) Onishenko G.G., Zaitseva N.V., Shur P.Z., Kiryanov D.A., Chigvintsev V.M., Khasanova A.A., Balashov S.Yu., 2015

Onishchenko Gennady Grigorievich - Assistant to Prime-Minister of the Russian Federation, Honored Doctor of the Russian Federation, Acamemician of the Russian (e-mail: depart @ gsen. ru; tel.: 8 (499) 973-27-44, 8 (499) 973-17-17).

Zaitseva Nina Vladimirovna - Doctor of Medicine, Professor, Academician of the Russian Academy of Sciences, Honored Scientist of Russia, Director (e-mail: znv@ fcrisk.ru; tel.: 8 (342) 237-25-34).

Shur Pavel Zalmanovich - Doctor of Medicine, Scientific Secretary (e-mail: shur@ fcrisk.ru; tel.: 8 (342) 238-33-37).

Kiryanov Dmitry Aleksandrovich - Ph.D. in Engineering Science, Head of the Department of Mathematical Modeling of Systems and Processes (e-mail: kdn@fcrisk.ru; tel.: 8 (342) 237-18-04).

Chigvintsev Vladimir Mikhailovich - researcher at the Department of Mathematical Modeling of Systems and Processes (e-mail: cvm@fcrisk.ru; tel.: 8 (342) 237-18-04).

Hasanova Anna Alekseevna - Master, Specialist of the Department of Risk Analysis (e-mail: sharaeva@fcrisk.ru; tel.: 8 (342) 238-33-37).

Balashov Stanislav Yurievich- Head of the Laboratory of Integrated Sanitary Analysis and Expertise (e-mail: stas@fcrisk.ru; tel.: 8 (342) 237-18-04). 
diet and spectrum of feeding [10]. The young fishes of many species and many adult fish eat plankton which can accumulate the radionuclides up to the concentrations which by the hundreds of times exceed the content of radionuclides in the surrounding water. That is why at the low content of radioactive substances in water their intake to the body of fich is stipulated mainly by the contaminated food. Herewith no effective transfer of radioisotope ${ }^{137} \mathrm{Cs}$ between the food levels zoobenthos - bottom-feeding fish occurs, however the accumulation of this radionuclide from the biomass of bottom-feeding fish by the ichthyophages is carried out [12]. The smallest quantity of ${ }^{137} \mathrm{Cs}$ is recorded for the bottomfeeding fish, plankton-eaters and phytophages, and the largest quantity of ${ }^{137} \mathrm{Cs}$ is specific for ichthyophages and fish with the mixed type of feeding [2].

When coming to the water ecosystems the radioisotopes are selectively accumulated by the separate components of water basin creating by this the different radiation conditions for each of ecological groups. The radionuclides are intensively absorbed by the bottom and bottom sediments which results in that the bottom becomes the certain depositary of long-living elements.

Due to the fact that isotope ${ }^{137} \mathrm{Cs}$ which has a long-term half-life period deposits on the particles of residuals and accumulates on the bottom as well as that the accumulation of radioisotopes for the bottom fish occurs quicker than for pelagians the bottom fish can become the most sensitive groups of sea inhabitans [19The measurement of radioactivity for different ecological types of fish demonstrated that for the bottom inhabitants the indicators are higher by $10-50$ times than for pelagians and subsurface species.

According to the data of Pacific Scientific and Research Fishery Center the Far Eastern yields consist of Alaska pollack, herring and Pacific salmon; at the same time the yield of such commercial fish as Pacific saury and Pacific bluefin tuna increases. The Pacific saury belongs to plankton-eaters, therefore, for this type no effective accumulation of ${ }^{137} \mathrm{Cs}$ isotopes during the process of feeding occurs, but the routes of its migration go through the regions worst contaminated with cesium as for the Pacific bluefin tuna. Together with it, the tune belongs to ichthyophages. In contrast to the Pacific saury and tune, the migration routes of Far Eastern sardine do no pass through the regions of Pacific Ocean covered by the radioactive contamination after the accident at Fukushima-1, however this type of fish has the mixed type of feeding, and due to this fact it is characterized by the effective accumulation of ${ }^{137} \mathrm{Cs}$ radioisotopes in the food web.
Therefore, due to the Fukushima-1 accident there is the hazard of the cesium isotopes intake with fish products exists, and it is necessary to assess the risk for the health of population of the Russian Federation associated with the consumption of these products.

The goal of work - to assess the safety for the health of population of the Russian Federation from the consumption of Far Eastern commercial fish due to the Fukushima-1 accident.

To achieve the goal the following tasks were solved:

1) selection of mathematical model describing the processo of dilution and transfer of radionuclides and analysis of the results of field ${ }^{137} \mathrm{Cs}$ measurements;

2) assessment of radionuclides content in the selected species of commercial fish taking into account the results of simulation of the levels of the ocean water contamination by cesium on the routes of their migration and field studies during the period up to 2014;

3) creating the fish products consumption scenarios and in accordance with them the calculation of the daily ${ }^{137} \mathrm{Cs}$ intake for the inhabitants of Far Eastern constituent entities of the Russian Federation;

4) assessment of risk for the health of population of the Russian Federation associated with the cesium radionuclides intake with fish products.

Materials and methods. The model proposed by the international research group of scientists from Spain, Australia and France (Institute for Cross-Disciplinary Physics and Complex Systems, Spain; University of New South Wales, Climate Change Research Center \& ARC Centre of Excellence for Climate System Science, Australia; Laboratoire d'Etude en Géophysique et Océanographie Spatiales, France) [14] was selected as the working model for the process of dilution and transfer of radionuclides. It describes the calculation for the distribution of the ${ }^{137} \mathrm{Cs}$ isotope content in the part of Pacific Ocean subjected to the impact of discharges due to the Fukushima-1 accident. The data provided in the work (fig. 1) allow not only to characterize the contamination of the northern part of Pacific Ocean in 2012 but also to perform the forecast for 10 years. The model takes into account all the main parameters of emergency discharge, characteristics of ocean currents, relief of bottom and atmospheric phenomena that allowed for its selection as basic to perform the verification procedure. 

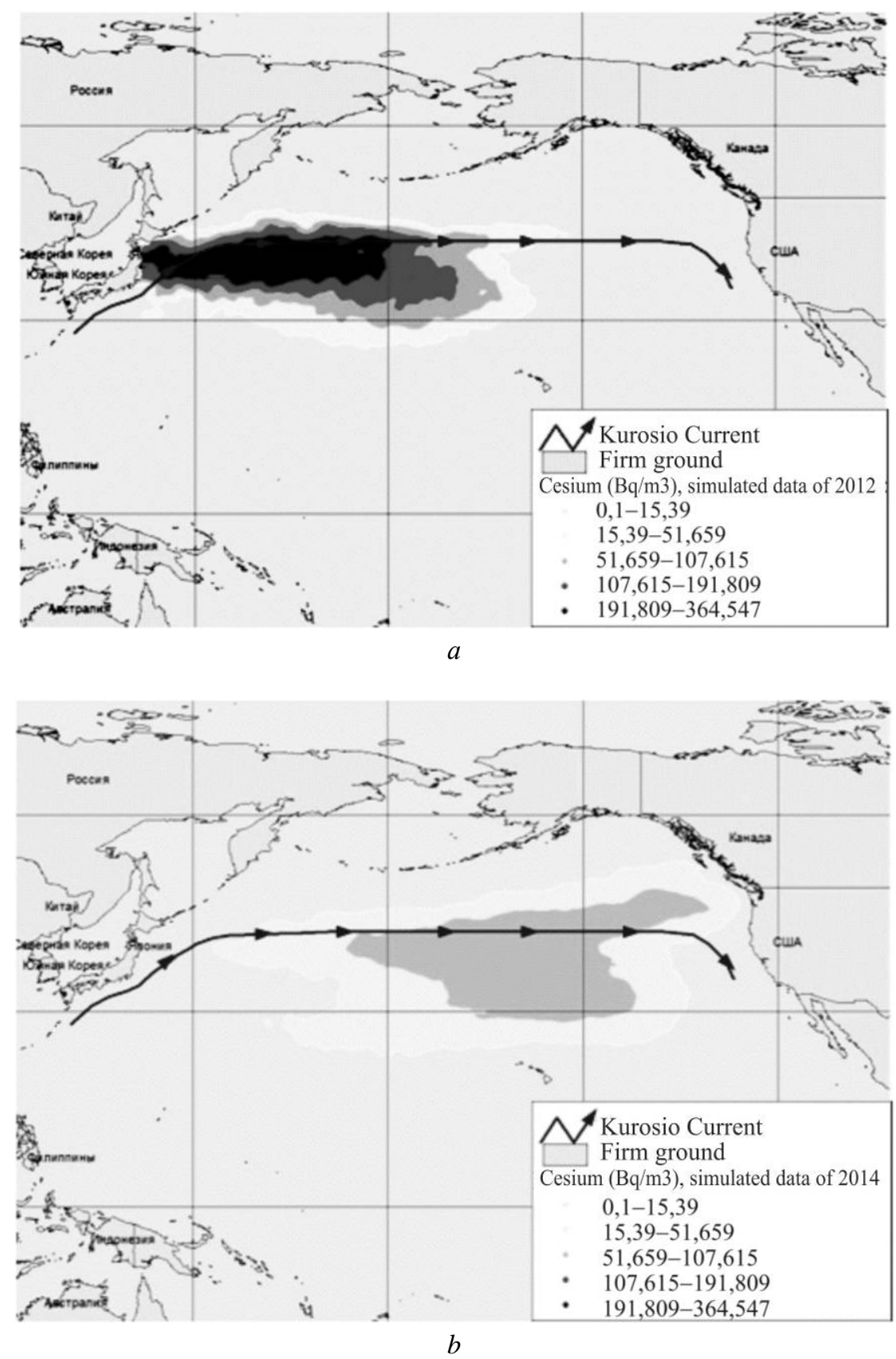

Fig. 1. Results of calculations for the spatial distribution of cesium ${ }^{137} \mathrm{Cs}$ : $a-2012 ; b-2014$

The data obtained during the scientific expeditions to the supposed contamination areas and in the organized systemic monitoring studies of the radioactive isotopes content were used as the basic information materials to calculate the values of field measurements. The sources were the results of studies of the Federal Budget Institution of Science "Saint-Petersburg Research Institute of Radiation Hygiene named after professor P.V. Ramzayev" of the surface water of the Sea of Japan and Pacific Ocean (nearby the place of accident), data obtained in the joint study in 2011 of the aquatic area of $\mathrm{Pa}$ cific Ocean between the shores of Japan and USA by the specialists from USA and Japan [15], and the public materials of monitoring studies of the sea water quality organized by Japan and USA $[15,17$, 18]. In total, the processing included the data for 4 years in relation to 909 measurements at the different depths and places of Pacific Ocean basin [15, $17,18]$.

The common characteristics of initial data collected from different sources: 
- for 2011 - 305 measurements (minimum $0.3 \mathrm{~Bq} / \mathrm{m}^{3}$, average $-229 \mathrm{~Bq} / \mathrm{m}^{3}$, maximum $\left.4496.8 \mathrm{~Bq} / \mathrm{m}^{3}\right)$;

- for 2012 - 83 measurements (minimum $0.8 \mathrm{~Bq} / \mathrm{m}^{3}$, average $-5.717 \mathrm{~Bq} / \mathrm{m}^{3}$, maximum $\left.76.7 \mathrm{~Bq} / \mathrm{m}^{3}\right)$;

- for 2013 - 353 measurements (minimum - 0 $\mathrm{Bq} / \mathrm{m}^{3}$, average $-3.036 \mathrm{~Bq} / \mathrm{m}^{3}$, maximum - 21 $\left.\mathrm{Bq} / \mathrm{m}^{3}\right)$;

- for 2014 - 167 measurements (minimum $0.4 \mathrm{~Bq} / \mathrm{m}^{3}$, average $-2.213 \mathrm{~Bq} / \mathrm{m}^{3}$, maximum -6.9 $\left.\mathrm{Bq} / \mathrm{m}^{3}\right)$.
Fig. 2 shows the geographic affixment of points to control the content of cesium in sea water. The control points geography analysis (fig. 2) demonstrated that practically all the points are located along the shores of North America, Japan and Kuril Ridge as well as along the Pacific current Kurosio.

The results of simulation of the cesium radionuclides distribution in the aquatic area of Pacif Ocean and the data of field measurements were used as the initial information to assess the content of radionuclides in the separate species of commercial fish.

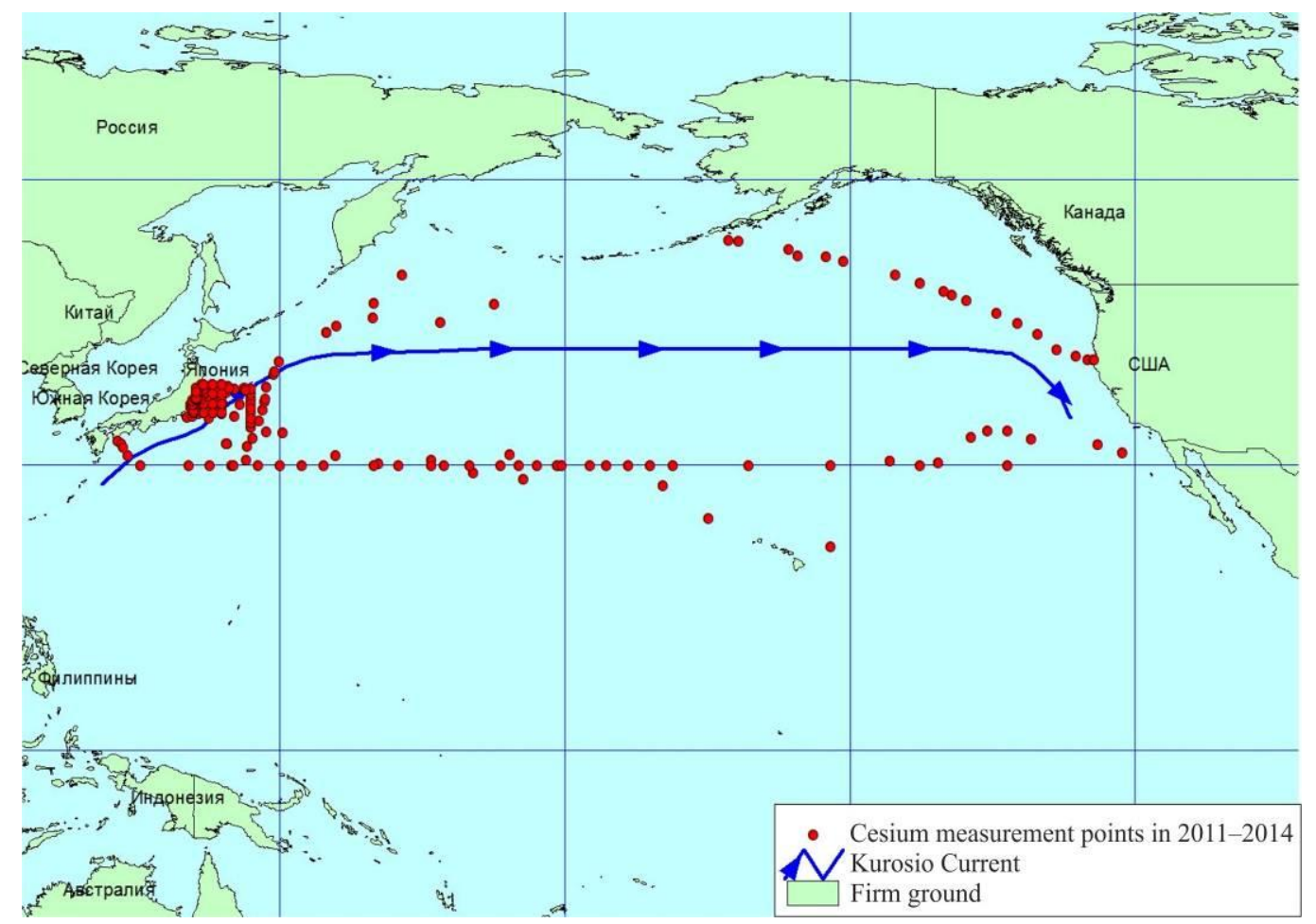

Fig. 2. Geographical affixment of points to control the content of cesium ${ }^{137} \mathrm{Cs}$ in sea water

The species of fish, for which the scenarios of concumption and the annual intake calculation based on them are created, were selected to assess the hazard and risk for the health of population of the Russian Federation associated with intake of cesium radionuclides with fish products.

The selection of the fish species the consumption of which will be taken into account during the development of the scenarios of concumption and the ${ }^{137} \mathrm{Cs}$ annual intake calculation based on them was stipulated by the routes of migration and the spectrum of feeding. The routes of migration for the selected fish species were displayed on the maps, together with indication of ${ }^{137} \mathrm{Cs}$ concentrations obtained according to the data of simulation of the cesium isotopes distribution process discharged to the ocean due to the Fukushima- 1 accident and the point of field measurements.

When assessing the consumption of fish and fish products in the Russian Federation we used the actual consumption values according to the data of the Federal State Statistics Service for 2013, as well as the consumption of fish and fish products by th risk groups - the inhabitants of population clusters at the islands of Sakhalin region which can be considered as the target group. The assessment of haard and risk for the health of population of the Russian Federation associated with the cesium radionuclides intake with fish products was performed in accordance with principles specified in R 2.1.10.1920-04 "Manual on the assessment of risk to the health of population when exposed to 
the chemical substances contaminating the environment".

The concentrated multipliers recommended by the International Atomic Energy Agency (IAEA) in the technical report TRS-422 [5] were used to calculate the concentration of radionuclides in fish, taking into account the obtained data in relation to the concentrations in sea water.

The evolution approach was used to calculate the carcinogenic risk in each scenario. The evolution model for the carcinogenic health risk accumulation during the consumption of products containing radionuclides is the mathematical description of changes in the health condition of population exposed to the long-term impact of radiation factors.

The evolution equations are recorded in the form of recurrent relations allowing for organizing the iteration calculation procedure under the time steps. The system of recurrent equations takes into account the accumulation of risk of carcinogenic effects for the critical organs/systems due to the action of different radionuclides. The model allows for calculation of carcinogenic risk at any ceratin moment using the forecasting of the effects risk accumulation, taking into account the age and exposure duration.

The risk of cancer at the radiation exposure is calculated under the following relation:

$$
R_{t+1}=R_{t}+\left(\alpha_{1} R_{t}+\lambda D_{t}\right) K
$$

where $R_{t+1}$ is a value of risk at the moment of time $t+1, R_{t}$ is a value of risk at the moment of time $t, \alpha_{1}$ is a risk increment rate at the expense of natural causes, $\lambda$ is a risk increment rate at the expense of radiation, $D_{t}$ is a radiation factor exposure (dependence of dose on time), $K$ is a time empirical coefficient.

The coefficients which take into account the evolution of risk at the expense of natural causes are determined based on the background indicators of morbidity and mortality from separate nosologies reflecting the functional disorders in the critical organs and systems (table 1). The indification of parameters for the models of the health disorders risk accumulation at the expense of natural processes in the body is performed based on the statistical data on the morbidity and mortality of adult population.

Table 1

Reccurent relation to assess the risk of cancer morbidity

\begin{tabular}{|l|c|}
\hline \multicolumn{1}{|c|}{ Nosology } & Relation \\
\hline Lung cancer & $R_{t+1}=R_{t}+\left(0,1255 R_{t}+4,12 \cdot 10^{-4} D_{t}\right) K$ \\
\hline Bladder cancer & $R_{t+1}=R_{t}+\left(0,135 R_{t}+0,55 \cdot 10^{-4} D_{t}\right) K$ \\
\hline Stomach cancer & $R_{t+1}=R_{t}+\left(0,139 R_{t}+0,71 \cdot 10^{-4} D_{t}\right) K$ \\
\hline Esophageal cancer & $R_{t+1}=R_{t}+\left(0,1 R_{t}+2,32 \cdot 10^{-4} D_{t}\right) K$ \\
\hline
\end{tabular}

The risk accumulation evolution models are used to calculate the radiation risk. In the firs year of life the value of risk is accepted as equal to $10^{-7}$.

Results and their discussion. The overlapping of the fish migration routes with the obtained design data (fig. 3) was performed to assess the content of radionuclides in the selected species of commercial fish.

The habitats and migration routes of Alaska Pollack, herring and Pacific salmon according to the results of the radionuclides distribution simulation are characterized by the minimal levels of contamination [8]. At the same time, the migration routes of such species of fish as Pacific saury and Pacific bluefin tuna go through the regions more contaminated by cesium $[8,13]$.
Some scenarios for the intake of ${ }^{137} \mathrm{Cs}$ to the body of people consuming the fish catched in $\mathrm{Pa}$ cific Ocean were considered according to the methodical approaches to the human health risk assessment associated with content of harmful substances in the food products accepted in the global pactice $[4,18]$. The created scenarios provide the design and field data for the measurements of ${ }^{137} \mathrm{Cs}$ concentrations in sea water for 2012 and 2014 as well as the consumption of fish products in the volume of $24.8 \mathrm{~kg}$ for the population in general and $50.0 \mathrm{~kg}$ for target groups. When creating the scenarios we considered the supposition assuming the level of incorporation equivalent to the maximum concentration of ${ }^{137} \mathrm{Cs}$ in sea water which does not change during the period of forecasting 
(without taking into account the half-life period of isoptope).

The incorporation providing the consumption of product in the volume of $24.8 \mathrm{~kg}$ per year [7] with the content of assessed component in accordance with design data for 2012 and 2014 was considered as the first scenario.
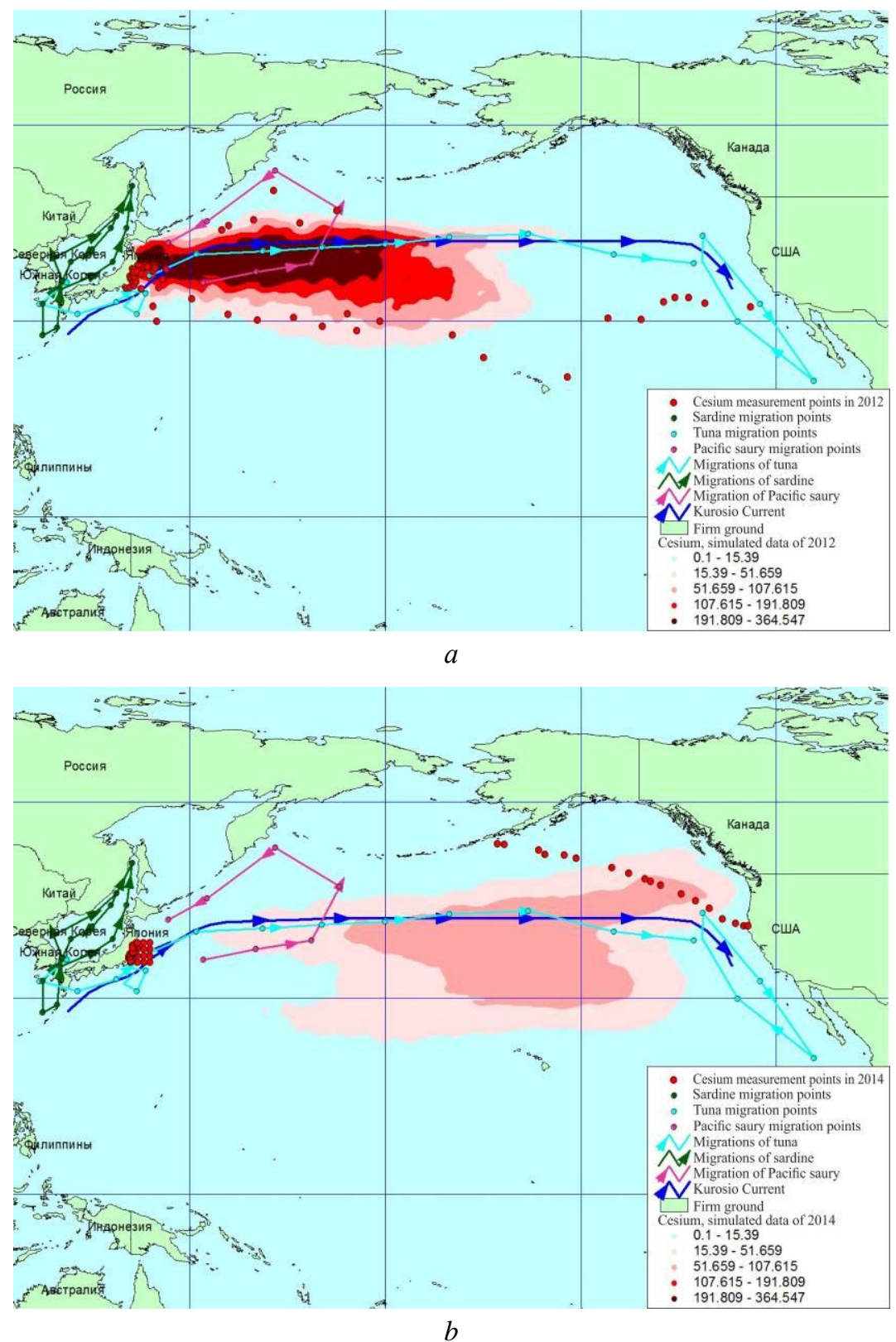

Fig. 3. Results of calculation of spatial distribution of cesium ${ }^{137} \mathrm{Cs}$ with overlapping of fish migration routes and points of field measurements (the concentration of cesium in sea water, $\mathrm{Bq} / \mathrm{m}^{3}$ ): $a-$ in $2012 ; b-$ in 2014.

The second scenario is considered for the target groups of populatin consuming up to $50.0 \mathrm{~kg}$ of fish products [9], with concentration of ${ }^{137} \mathrm{Cs}$ radionuclide also obtained as a result of calculations. The third and fourth scenarios provided the use of data from the field measurements of ${ }^{137} \mathrm{Cs}$ concentrations in water for 2012 and 2014 at the consumption of fish products by population in the volume of 24.8 and $50.0 \mathrm{~kg}$.
The concentrations of ${ }^{137} \mathrm{Cs}$ radionuclides in the migration areas of Pacific bluefin tuna and $\mathrm{Pa}-$ cific saury are provided in tables 2 and 3 .

Maximum concentrations of ${ }^{137} \mathrm{Cs}$ radionuclides in the migration areas of Pacific bluefin tuna are as follows: according to the data of simulation -311.9 $\mathrm{Bq} / \mathrm{m}^{3}$ in 2012 (point 4) and $72.5 \mathrm{~Bq} / \mathrm{m}^{3}$ in 2014 (point 8), according to the data of field studies $-5 \mathrm{~Bq} / \mathrm{m}^{3}$ 
(point 4) in 2012 and $2.7 \mathrm{~Bq} / \mathrm{m}^{3}$ in 2014 (point 1). Maximum concentrations of ${ }^{137} \mathrm{Cs}$ radionuclides in the migration areas of Pacific saury are as follows: according to the design data $-271.8 \mathrm{~Bq} / \mathrm{m}^{3}$ (points 2 and 3) in 2012 and $35.1 \mathrm{~Bq} / \mathrm{m}^{3}$ (point 3) in 2014, according to the data of field studies $-5.4 \mathrm{~Bq} / \mathrm{m}^{3}$ (point 4) in 2012 and $3 \mathrm{~Bq} / \mathrm{m}^{3}$ (point 7) in 2014.

Incompliance of assessments of the sea water contamination with ${ }^{137} \mathrm{Cs}$ under the results of simulation and field studies evidences the existing hazard of the cesum isotopes distribution and necessity to continue the monitoring.
The performed assessment of ${ }^{137} \mathrm{Cs}$ radionuclides in the selected fish species is specified in tables 4 and 5 .

According to the design data, the bluefin tuna could contain $31.1 \mathrm{~Bq} / \mathrm{kg}{ }^{137} \mathrm{Cs}$ in 2012 and 7.3 $\mathrm{Bq} / \mathrm{kg}$ in 2014. According to this, the annual intake of ${ }^{137} \mathrm{Cs}$ to the human body with bluefin tuna in 2012 will be $771.25 \mathrm{~Bq}$, and in $2014-181.04 \mathrm{~Bq}$. For the target groups of population (annual consumption of fish products up to $50 \mathrm{~kg}$ ) the annual intake of ${ }^{137} \mathrm{Cs}$ to the human body will be 1555.0 and $365.0 \mathrm{~Bq}$ in 2012 and 2014, respectively.

Table 2

Concentrations of ${ }^{137} \mathrm{Cs}$ radionuclides in the migration areas of Pacific bluefin tuna and Pacific saury according to the data of simulation ${ }^{1}$

\begin{tabular}{|c|c|c|c|c|c|}
\hline \multirow{2}{*}{ Species } & \multirow{2}{*}{ Point No. } & \multirow{2}{*}{ Latitude } & \multirow{2}{*}{ Longitude } & \multicolumn{2}{|c|}{ Concentration in water, $\mathrm{Bq} / \mathrm{m}^{3}$} \\
\hline & & & & 2012 & 2014 \\
\hline \multirow[t]{19}{*}{ Bluefin tuna } & 1 & 131.25 & 35.89 & 0.1 & 0.1 \\
\hline & 2 & 126.96 & 32.68 & 0.1 & 0.1 \\
\hline & 3 & 132.86 & 31.07 & 0.1 & 0.79 \\
\hline & 4 & 138.75 & 32.95 & 0.44 & 1.61 \\
\hline & 5 & 143.3 & 34.29 & 29.52 & 3.82 \\
\hline & 6 & 141.96 & 31.07 & 14.97 & 5.98 \\
\hline & 7 & 143.84 & 36.96 & 148.36 & 4.84 \\
\hline & 8 & 151.07 & 40.18 & 200.81 & 10.57 \\
\hline & 9 & 161.25 & 40.71 & 311.91 & 22.21 \\
\hline & 10 & 170.36 & 41.25 & 269.33 & 47.13 \\
\hline & 11 & 180.0 & 41.79 & 200.81 & 54.08 \\
\hline & 12 & 189.91 & 42.86 & 72.54 & 63.21 \\
\hline & 13 & 201.96 & 43.39 & 35.14 & 72.54 \\
\hline & 14 & 215.1 & 40.18 & 0.24 & 47.13 \\
\hline & 15 & 227.41 & 38.84 & 0.1 & 10.57 \\
\hline & 16 & 228.75 & 43.13 & 0.1 & 20.83 \\
\hline & 17 & 234.11 & 30.0 & 0.1 & 2.90 \\
\hline & 18 & 245.8 & 20.89 & 0.1 & 0.1 \\
\hline & 19 & 237.6 & 32.68 & 0.1 & 1.15 \\
\hline \multirow[t]{7}{*}{ Pacific saury } & 1 & 152.14 & 35.89 & 175 & 5.12 \\
\hline & 2 & 160.18 & 37.5 & 271.81 & 16.56 \\
\hline & 3 & 168.75 & 38.84 & 271.81 & 35.14 \\
\hline & 4 & 173.04 & 47.14 & 2.46 & 5.46 \\
\hline & 5 & 163.13 & 53.04 & 0.78 & 0.90 \\
\hline & 6 & 152.68 & 45.27 & 10.57 & 1.38 \\
\hline & 7 & 146.79 & 42.05 & 130.48 & 6.87 \\
\hline
\end{tabular}

Table 3

Concentrations of ${ }^{137} \mathrm{Cs}$ radionuclides in the migration areas of Pacific bluefin tuna and Pacific saury according to the data of field studies ${ }^{1}$

\begin{tabular}{|c|c|c|c|c|c|}
\hline \multirow{2}{*}{ Species } & \multirow{2}{*}{ Point No. } & \multirow{2}{*}{ Latitude } & \multirow{2}{*}{ Longitude } & \multicolumn{2}{|c|}{ Concentration in water, $\mathrm{Bq} / \mathrm{m}^{3}$} \\
\hline & & & & 2012 & 2014 \\
\hline \multirow[t]{4}{*}{ Bluefin tuna } & 4 & 138.75 & 32.95 & 1.8 & 2.7 \\
\hline & 5 & 143.3 & 34.29 & 1.7 & 2.2 \\
\hline & 6 & 141.96 & 31.07 & 1.6 & 1.6 \\
\hline & 7 & 143.84 & 36.96 & 2.6 & 2 \\
\hline
\end{tabular}

\footnotetext{
${ }^{1}$ Institute for Cross-Disciplinary Physics and Complex Systems, Spain; University of New South Wales, Climate Change Research Center \& ARC Centre of Excellence for Climate System Science, Australia; Laboratoire d'Etude en Géophysique et Océanographie Spatiales, France.
} 


\begin{tabular}{|c|c|c|c|c|c|}
\hline & 9 & 161.25 & 40.71 & 5 & - \\
\cline { 2 - 6 } & 17 & 234.11 & 30.0 & 1.7 & - \\
\cline { 2 - 6 } & 19 & 237.6 & 32.68 & 1.7 & - \\
\hline Pacific saury & 1 & 152.14 & 35.89 & 3.7 & - \\
\cline { 2 - 6 } & 4 & 173.04 & 47.14 & 5.4 & - \\
\cline { 2 - 6 } & 5 & 163.13 & 53.04 & 1.8 & - \\
\cline { 2 - 6 } & 6 & 152.68 & 45.27 & 4.3 & 3 \\
\cline { 2 - 6 } & 7 & 146.79 & 42.05 & 4.3 & \\
\hline
\end{tabular}

Table 4

Assessment of ${ }^{137} \mathrm{Cs}$ concentrations in the fish species selected for simulation (according to the design concentrations in sea water)

\begin{tabular}{|l|c|c|}
\hline \multirow{2}{*}{ Species } & \multicolumn{2}{c|}{ Concentration in fish (Bq/kg) } \\
\cline { 2 - 3 } & 2012 & 2014 \\
\hline Bluefin tuna & 31.1 & 7.3 \\
\hline Pacific saury & 27.18 & 3.5 \\
\hline
\end{tabular}

Table 5

Assessment of ${ }^{137} \mathrm{Cs}$ concentrations in the fish species selected for simulation (according to the field measurements in sea water)

\begin{tabular}{|l|c|c|}
\hline \multirow{2}{*}{ Species } & \multicolumn{2}{|c|}{ Concentration in fish (Bq/kg) } \\
\cline { 2 - 3 } & 2012 & 2014 \\
\hline Bluefin tuna & 0.5 & 0.27 \\
\hline Pacific saury & 0.54 & 0.3 \\
\hline
\end{tabular}

Also the annual intake of ${ }^{137} \mathrm{Cs}$ to the human body according to the data of field observations is calculated: at the consumption of sea fish on the basis of $24.8 \mathrm{~kg}$ (according to the third scenario) in 2012 the incorporation of ${ }^{137} \mathrm{Cs}$ is $12.4 \mathrm{~Bq}$, and in $2014-$ $6.7 \mathrm{~Bq}$; at the consumption of up to $50.0 \mathrm{~kg}$ of bluefin tuna (the fourth scenario) $-25.0 \mathrm{~Bq}-$ in 2012 and 13.5 Bq - in 2014 (table 6).

The results evidence that the annual incorporation of ${ }^{137} \mathrm{Cs}$ in all the scenarios of the annual consumption limit of this isotope of cesium recommended below with food for population is 77 $000 \mathrm{~Bq}$ per year [11].

The daily intake of ${ }^{137} \mathrm{Cs}$ due to the sea fish consumption in the amount of 24.8 and $50.0 \mathrm{~kg}$ per year was calculated for the evolution risk simulation tasks. The results of calculations are provided in table 7.
The scenarios No. 1-4 at which the daily intake of ${ }^{137} \mathrm{Cs}$ during the whole life is equal to the maximum daily intake of ${ }^{137} \mathrm{Cs}$ obtained in scenario were used to calculate the indicators of additional life-long mortality and cancer morbidity.

According the daily intake of cesium-137 with fish maximum for each scenario under the carcinogenic risk evolution simulation the additional carcinogenic risk value in the age of 80 years for scenario No. 1 was $2.7310^{-6}$; for scenario No. 2 - 5.48 $10^{-6}$; for scenario No. $3-5.1310^{-8}$ and for scenario No. $4-9.5210^{-9}$. The life-long additional risk was: scenario No. $1-7.210^{-6}$; No. $2-1.4610^{-5}$; No. $3-$ $1.3710^{-7}$; No. $4-2.510^{-8}$. The level of additional risk $10^{-6}$ for scenario No. 1 is achieved in the age of 70 years, for scenario No. 2 - in the age of 66 years, for scenarios No. 3 and 4 it is not achieved during the whole life (fig. 4).

Annual intake of ${ }^{137} \mathrm{Cs}$ at the consumption of fish products (bluefin tuna) (Bq/year)

\begin{tabular}{|c|c|c|}
\hline Scenario & 2012 & 2014 \\
\hline 1 & 771.28 & 181.04 \\
\hline 2 & 1555.0 & 365.0 \\
\hline 3 & 12.4 & 6.7 \\
\hline 4 & 25.0 & 13.5 \\
\hline
\end{tabular}


Daily intake of ${ }^{137} \mathrm{Cs}$ at the consumption of fish products (bluefin tuna) (Bq/day)

\begin{tabular}{|c|c|c|}
\hline Scenario & 2012 & 2014 \\
\hline 1 & 2.12 & 0.5 \\
\hline 2 & 4.26 & 1.0 \\
\hline 3 & 0.04 & 0.02 \\
\hline 4 & 0.007 & 0.04 \\
\hline
\end{tabular}

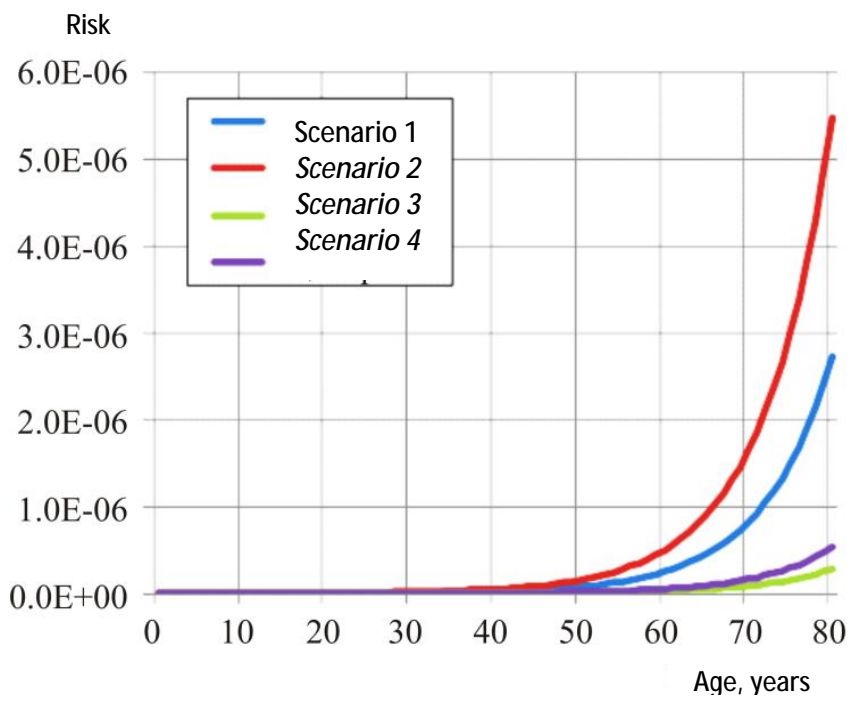

Fig. 4. Additional carcinogenic risk

According to the system of criteria proposed by the World Health Organization and adopted in the Russian Federation during the health risk analysis the obtained values are assessed as the minimum risk.

Conclusions. According to the results of the ${ }^{137} \mathrm{Cs}$ distribution simulation the area of contamination covers the significant part of the aquatic area of Pacific Ocean, including the migration routes of commercial fish and fishing zones. Incompliance of assessments of the sea water contamination with ${ }^{137} \mathrm{Cs}$ under the results of simulation and field studies evidences the existing hazard of the cesum isotopes distribution and necessity to continue the monitoring.

The assessment of risk to the health of population of the Russian Federation associated with the fish products consumption performed under the scenario which takes into account the maximum possible accumulation of cesium radionuclides in fish and maximum consumption of the fish products demon- strated that as of 2014 the maximum intake of ${ }^{137} \mathrm{Cs}$ with fish to the body of inhabitants of the Far Eastern regions of Russia did not exceed $365 \mathrm{~Bq}$ per year that is significantly lower than the safe annual intake limit and complies with the acceptable health risk.

The simulation of evolution of carcinogenic risk associated with intake of cesium-137 at the fish products consumption demonstrated that during the whole life the level of this risk is classified as minimum.

Together with it, due to the existing hazard of the contamination of ocean by the cesium radionuclides from Fukushima-1 if the additional data on the discharges of radioactive water will be available, it is necessary to carry out the repeated studies on assessing the risk to the health of population of the Russian Federation. 


\section{References}

1. Romanovich I.K., Balonov M.I., Barkovskij A.N., Nikitin A.I. Avarija na AJeS «Fukusima-1»: organizacija profilakticheskih meroprijatij, napravlennyh na sohranenie zdorov'ja naselenija Rossijskoj Federacii [The accident at the nuclear power plant "Fukushima-1": organization of preventive measures aimed at maintaining the health of the Russian population]. Saint-Petersburg: NIIRG im. prof. P.V. Ramzaeva, 2012. 336 p. (in Russian).

2. Zarubin O.L., Malyuk I.A., Kostyuk V.A. Osobennosti soderzhanija 137Cs u razlichnyh vidov ryb Kanevskogo vodohranilishha na sovremennom jetape [Features of 137Cs in different fish species Kanev Reservoir at the present stage]. Gidrobiologicheskij zhurnal. 2009, vol. 45 (5), pp. 110-116 p. (in Russian)

3. Ramzaev V.P., Ivanov S.A., Goncharov Ju.N., Vishnjakova N.M., Sevast'janov A.V. Issledovanie radioaktivnogo zagrjaznenija morskoj bioty v svjazi s avariej na AJeS «Fukusima-1» [Investigation of radioactive pollution of the marine biota in connection with the accident at the plant "Fukushima-1"]. Radiacionnaja gigiena, 2012 ; vol. 4: pp. 5-11. (in Russian)

4. Codex Alimentarius Commission. Procedural Manual. Twenty-first edition, FAO / WHO, Rome, 2013.

5. Kojefficienty raspredelenija $\mathrm{v}$ otlozhenijah i koncentracionnye mnozhiteli dlja bioty v morskoj srede [Distribution ratios in sediments and biota concentration factors in the marine environment]. IAEA, 2004. Available at: http://wwwpub.iaea.org/MTCD/publications/PDF/TRS422_web.pdf

6. Polyakova N.I. Features Cs accumulation in fish of different trophic levels of the reservoirs, contaminated as a result of the Chernobyl accident: thesis abstract on scientific degree of candidate of biological sciences (03.00.10). Institut problem jekologii i jevoljucii im. A.N. Severcova RAN, 2008, 25 p. (in Russian)

7. Potreblenie osnovnyh produktov pitanija naseleniem Rossijskoj Federacii [Consumption of basic foodstuffs population of the Russian Federation. Federal State Statistics Service]. Available at: http://www.gks.ru/ (in Russian)

8. Repin V.S. Radiacionno-gigienicheskaja ocenka vozmozhnyh urovnej zagrjaznenija dal'nevostochnyh moreproduktov dolgozhivushhimi radionuklidami v svjazi s avariej na AJeS «Fukusima-1» [Radiation-hygienic assessment of possible pollution levels Far East Seafood long-lived radionuclides in connection with the accident at the nuclear power plant "Fukushima-1"]. Radiacionnaja gigiena, 2012, vol. 2 (5), pp. 61-77. (in Russian)

9. Romanovich I.K., Gromov A.V., Goncharova Ju.N. Predvaritel'nyj analiz dannyh pervichnogo obsledovanija radiacionnoj obstanovki v jugo-vostochnyh rajonah Sahalinskoj oblasti posle avarii na AJeS «Fukusima-1» [Preliminary analysis of the data of the primary survey of the radiation situation in the south-eastern Sakhalin region after the Chernobyl nuclear power plant "Fukushima-1"]. Radiacionnaja gigiena, 2011, vol. 4, no. 3, pp. 3642. (in Russian)

10. Rjabov I.N. Radiojekologicheskie osobennosti ryb, prinadlezhashhih k razlichnym faunisticheskim kompleksam [Radiological features of fish belonging to different faunal complexes]. IV sezd po radiacionnym issledovanijam (radiobiologija, radiojekologija, radiacionnaja bezopasnost'). Moscow, 2001; vol. II. 565 p. (in Russian)

11. Radiation Safety Standards NRB-99/2009. Sanitary rules and regulations SanPiN 2.6.1.2523 - 09. Moscow, 2009, $137 \mathrm{p}$.

12. Trofimova E.A., Zotina T.A., Bolsunovskij A.Ja. Ocenka jeffektivnosti perenosa tehnogennyh radionuklidov mezhdu komponentami troficheskih setej r.Enisej [Evaluating the effectiveness of the transfer of radionuclides between the components of food webs Yenisey]. Materialy Mezhdunarodnoj molodezhnoj shkoly-seminara «Geohimija zhivogo veshhestva» (Tomsk, 2-5 ijunja 2013 g.). Tomsk: Izd-vo Tomskogo politehnicheskogo universiteta, 2013, pp. 178-180.

13. Daniel J. Madigan, Z. Baumannand, S. Fisher. Pacific bluefin tuna transport Fukushima-derived radionuclides from Japan to California. Proc Natl Acad Sci U S A, 2012, Jun 12; vol. 109 (24), pp. 9483-9486.

14. Rossi V., Sebille E.V., Gupta A.S., Garcon V., Matthew H. England «Multi-decadal projections of surface and interior path ways of the Fukushima Cesium-137 radioactive plume». Deep-Sea Research I. Available at: http://dx.doi.org/10.1016/j.dsr.2013.05.015

15. Ken O. Buesseler, Steven R. Jayne, Nicholas S. Fisher, Irina I. Rypina, Hannes Baumann, Zoa Baumann, Crystaline F. Breier, Elizabeth M. Douglass, JenniferGeorge, Alison M. Macdonald, Hiroomi Miyamoto, Jun Nishikawa, Steven M. Pike, and Sashiko Yoshida. Fukushima-derived radionuclides in the ocean and biota off Japan. PNAS, 2012, vol. 109, pp. 5984-5988.

16. Ken O. Buesseler. Fishing for answers off Fukushima. Science, 2012, vol. 338, pp. 480-482.

17. Monitoring information of environmental radioactivity level. Available at: http://radioactivity.nsr.go.jp/en/ index.html (10.12.2014).

18. Our Radioactive Ocean. Available at: http://ourradioactiveocean.org/results.html.

19. Yoshida N., Kanda J. Tracking the Fukushima Radionuclides. Science, 2012, vol. 336, pp. 1115-1116. 